\title{
Possible Adverse Effects of Increasing Block Water Tariffs in Developing Countries*
}

\author{
Dale Whittington \\ University of North Carolina at Chapel Hill
}

\section{Introduction}

The use of increasing block water tariffs is widespread throughout developing countries. An increasing block tariff (IBT) is a price structure in which a commodity is priced at a low initial rate up to a specified volume of use (block), then at a higher or several increasingly higher rates for additional blocks used. The ordinary household municipal water bill in developing countries is often calculated on some sort of IBT structure, and donor organizations and consultants continue to recommend this practice for town and city water systems. The majority of World Bank-sponsored water tariff studies conducted since 1970, for example, have recommended the use of increasing block water tariffs.

There are two commonly accepted justifications for using IBTs. The first, based on a rationale of equity, is that IBTs should assist low-income households and ensure an equitable allocation of the costs of water production and distribution. The argument in this case is that low-income households use less water than high-income households because they have fewer water-using appliances and are less likely to have large lawns and gardens. ${ }^{1}$ An IBT results in higher marginal prices to the customer - and thus higher average prices-for higher-income households. The price of water in the initial block may be set very low, usually at a subsidized rate, to ensure that the poor are not discouraged from using the amount of water considered essential for human needs (typically estimated at 25-50 liters per capita per day). The price of water in the initial block is thus sometimes termed the "lifeline rate." The second justification for IBT structures is that the higher prices charged beyond the initial block discourage "extravagant" water use and promote water conservation.

Both these justifications for IBTs assume that each household has 
its own metered water connection. That situation is true in many cities in industrialized countries, where the IBT structure was developed and first introduced. ${ }^{2}$ But in developing countries it is often the case that an individual household does not have its own metered water connection. In many African cities, for example, many people live in apartment buildings or compounds that they share with other households. Such housing units often have only a single water meter; the water utility presents the landlord, or the tenants as a group, with a single water bill, and the tenants must devise ways of dividing up the costs as equitably as they can. In some instances households with more members are required to pay a larger share; in others, households pay according to the number of rooms occupied. Many other households in developing countries have unmetered connections or no water connection at all. Households without connections often obtain their water from public systems indirectly, purchasing it either from neighbors who do have connections or from water vendors who fill their trucks or containers from public systems.

These two realities - shared water connections and indirect purchasing-have important implications for the design of water tariffs in developing countries. In such situations IBT structures may actually have the opposite effect than the intended equity objective; they may penalize low-income households instead of helping them. This unintended consequence occurs for two reasons.

First, poor households often live in more densely crowded housing and share buildings and compounds with many more households than do higher-income families. (Although high-quality large apartment buildings for upper-income households certainly exist, in many cities these are probably more likely to have individually metered household water connections.) If all households used the same amount of water, it is clear that the more households that share a single water connection in a building or compound, the more units of water will be used through that single connection. If an IBT is in effect, this high rate of use pushes the water bill for the building as a whole into the higher-priced blocks. The marginal price paid for water increases, and so does the average price paid. ${ }^{3}$ To the extent that poor people are more apt to live in high-density housing and share a common metered water connection, they will pay higher average prices for water.

The second detrimental effect of an IBT structure arises because many households do not have private water connections and purchase water from neighbors or vendors-in some cities these households make up the majority of the population. ${ }^{4}$ Households selling water may have either metered or unmetered connections. Metered connections are often billed through an IBT structure, unmetered connections through a flat rate regardless of the level of consumption. Sometimes households with connections sell water to neighbors at minimal cost as a courtesy, but often sales of water are a significant source of house- 
hold income and are organized as a business operation. The buyershouseholds without private water connections-are more likely to be poor than are households with such connections.

A household that has an unmetered water connection can sell water to other households at essentially zero marginal cost. The more buyers there are, the more profit to the seller once the flat-rate water bill is paid. In these cases sales are often arranged on the basis of a flat monthly fee for access to the connection, without stringent limits on the amount consumed. Obviously, unmetered connections can cause significant losses of revenue to the water utility.

On the other hand, if household connections are metered, households selling water must pay more careful attention to the amount of water collected by neighbors. The seller may still charge the buyer a flat rate, but there is often an implicit or explicit agreement that the buyer is entitled to collect a certain number of buckets of water per day or per week. Or the seller may charge for each bucket collected. This requires higher management costs for the seller but typically results in greater control over the quantity of water dispensed and in higher revenues to the connected household. With either payment arrangement-flat rate or pay by the bucket-IBTs for metered connections may adversely affect low-income households. Even a singlefamily household that sells water to neighbors soon faces the same situation as the large apartment building with one tap-the more units dispensed, the higher the marginal price of the water from that tap. The same rising prices apply to vendors who fill tanker trucks or other containers from metered taps. It is likely that sellers pass these increased costs on to the individual buyers.

Thus it happens that the poor, who are the most likely to lack water connections and who are obliged to purchase their water from neighbors or commercial vendors, often pay the most per unit for it. This is due to the high marginal (and average) prices paid to the water utility by households with connections. (When setting the price for their neighbors, such households presumably would raise the price of water even higher to collect a profit for themselves.) The magnitude of this effect of IBTs on the price of vended water is small because the cost of water is a small proportion of the vendors' total cost of supplying water. (On the other hand, this adverse effect of IBTs is more widespread than the first detrimental effect of IBTs described because it does not depend on the existence of shared metered connections.)

\section{An Example of How IBTs Penalize Households in High-Density Housing}

The actual water tariff structure in effect in Ghana in the summer of 1989 was ostensibly designed to assist low-income households and can be used to illustrate the magnitude of the effect of IBTs on the monthly 
water bill of households that share a single metered connection and live in high-density housing. For the first 3,000 gallons of water purchased each month, households throughout Ghana paid 184 cedis (ca. US $\$ 0.53$ ) per 1,000 gallons, with a minimum charge of 552 cedis per month. ${ }^{5}$ For consumption above 3,000 gallons and below 10,000 gallons per month, they paid 316 cedis (about US\$0.90) per 1,000 gallons. For consumption above 10,000 gallons per month the rate was 460 cedis (US\$1.31) per 1,000 gallons.

Consider first a household that shares a building and a single water connection with one other household. Assuming that each household has five members and that each person uses 10 gallons of water per day, each household uses 50 gallons per day and thus 1,500 gallons a month. The total water used by the two households is 3,000 gallons per month, and their joint bill amounts to 552 cedis, or 276 cedis per household.

Now consider a household that shares a building and a single water connection with 19 other households, each also with five members who use 10 gallons of water apiece per day. Total water used by each household is still 1,500 gallons per month, but the total water use for the entire building, through the shared single connection, is 30,000 gallons per month. Following the IBT structure outlined above, the water bill for the building will be 184 cedis per 1,000 gallons for the first 3,000 gallons (552 cedis), plus 316 cedis per 1,000 gallons for the next 7,000 gallons $(2,212$ cedis $)$, plus 460 cedis per 1,000 gallons for the final 20,000 gallons $(9,200$ cedis $)$-for a total of 11,964 cedis, or 598 cedis per household.

In this example, a household living in a building with 19 other households must pay more than twice as much per month for the same amount of water as a household that shares a building with only one other household. It is clear that the existing IBT structure in Ghana can create a dramatic rise in the average price of water for households that live in high-density housing.

This does not mean, however, total water expenditures for households living in high-density conditions would increase by the same magnitude because water use per capita is likely to be lower in more crowded housing situations. This is true for two principal reasons. First, households living in more crowded conditions probably face greater social restrictions on water use, including longer queue times at the tap during periods of peak use, and fewer convenient options for bathing, clothes washing, and disposal of sullage water. Second, lowincome households are likely to use less water than high-income households because of a positive income elasticity of demand for water. ${ }^{6}$

\section{Evidence from Kumasi, Ghana}

Household data from a recent study of water and sanitation conditions in Kumasi, Ghana, support the argument made in this article that in 
some common situations increasing block water tariffs do not help the poor. The study was conducted in November 1989 as part of a World Bank research project on demand for improved sanitation in Kumasi. Information was collected from a random sample of households throughout the city on (among other things) the household's assets, weekly expenditures, sources of water, monthly water expenditures, number of households sharing the building or compound, and whether the building's water bill was shared and, if so, how it was shared.

The survey results show that about $89 \%$ of Kumasi's 600,000 people are tenants. The housing stock is old, and conditions are very crowded; $90 \%$ of the sample households lived in a single room. On average there were more than 11 households ( 50 people) in a building or compound. Twenty-five percent of the households in the sample lived in multistory tenement buildings, another $70 \%$ lived in singlestory multifamily compounds. Multistory apartment buildings tend to be of higher-quality construction than many single-story compounds and tend to have the largest number of households.

Thirty-two percent of the sample households bought water from neighbors who had private connections to the public water system. Another $10 \%$ relied on public taps and neighbors' wells. The rest, approximately $58 \%$, had shared access to a connection in their building or compound; in most cases (85\%) these were metered connections, and $95 \%$ of the meters were working.

There were three principal methods of allocating the monthly water bill among families that shared a connection in a building or compound (see table 1). About $37 \%$ used a system of points, which were most commonly assigned on the basis of number of persons per household. But $35 \%$ indicated that points were assigned according to the number of rooms per household, and another $22 \%$ said that in their buildings the bill was divided equally among households regardless of size.

Respondents were not asked directly how much water their household consumed per month because only a few would have been able to make an accurate estimate. However, for those respondents who share the water bill for the building equally among households, it is

\section{TABLE 1}

Methods Used by Tenants to Share Water Bill

\begin{tabular}{lc}
\hline Method Used to Share & Percentage of Sample \\
Water Bill & 37 \\
\hline By points & 35 \\
By room & 22 \\
By household & 6 \\
Other & \\
\hline
\end{tabular}


possible to estimate their monthly water use and the average price they pay for water. Because such respondents were asked the amount of their monthly water bill and how many other households lived in the building or compound, the total water bill for the building can be estimated by multiplying the respondent's reported monthly share of the water bill by the number of households in the building. Because the tariff structure is known, the total water use for the building can be calculated from the estimated water bill. Dividing the total water consumption for the building by the number of households yields an estimate of the average household water use. Dividing the household's share of the monthly water bill by the estimate of the average household water use yields the average price of water to the household.

Table 2 presents these estimates of average household water use and the average price of water for households living in different-sized apartment buildings or compounds. ${ }^{7}$ As anticipated, the average price of water clearly increases as the number of households living in a building increases. Also as expected, households in buildings that are occupied by fewer additional households consume more water than households in buildings with greater numbers of households.

Table 3 presents the results of a regression analysis in which the average price paid for water is regressed on the number of households in the building. As hypothesized, the number of households in the building has a positive and highly significant impact on the average price of water paid by the household. The IBT structure thus appears to be raising the price of water paid by households living in highdensity conditions, just as predicted. The next question to examine is how this unintended consequence of the IBT structure affects the poor in Kumasi.

Three types of data were collected in the household interviews,

TABLE 2

Number of Households Per Building versus Household Water Use and Average Price of Water

\begin{tabular}{lcc}
\hline $\begin{array}{l}\text { Households per } \\
\text { Building or } \\
\text { Compound* }\end{array}$ & $\begin{array}{c}\text { Average Household } \\
\text { Water Use } \\
\text { (Gallons per Month) }\end{array}$ & $\begin{array}{c}\text { Average Price } \\
\text { of Water } \\
\text { (Cedis per Gallon) } \dagger\end{array}$ \\
\hline $1-4(10)$ & 1,865 & .25 \\
$5-8(15)$ & 1,188 & .29 \\
$9-12(23)$ & 1,145 & .32 \\
$13-16(22)$ & 838 & .33 \\
$17-20(5)$ & 781 & .36 \\
$>20(9)$ & 631 & .36 \\
\hline
\end{tabular}
vations.

* Numbers in parentheses are the number of household obser-

$\dagger$ In 1989 , US $\$ 1=350$ cedis. 
TABLE 3

REGRESSION RESULTS

\begin{tabular}{lccc}
\hline Dependent Variable & $\begin{array}{c}\text { Parameter } \\
\text { Estimate }\end{array}$ & $t$-statistic & $\begin{array}{c}\text { Significance } \\
\text { Level }\end{array}$ \\
\hline $\begin{array}{l}\text { Intercept } \\
\text { Number of households } \\
\text { in building }\end{array}$ & .24 & 20.7 & .0001 \\
\hline
\end{tabular}

NotE. - The dependent variable is the average price of water paid by the household (mean $=.31$ cedis per gallon) $F$ value $=43.9 ; N=72$; $R^{2}=.38$; adjusted $R^{2}=.37$.

which can be used to characterize a household's socioeconomic level. First, respondents were asked whether their household owned various consumer goods (e.g., radio, sewing machine, fan, refrigerator, television, automobile). One measure of a household's socioeconomic status is a simple count of the total number of assets owned by the household (i.e., without regard to the value of the different assets).

Second, almost all households in Kumasi have electricity in their flat, and most share a common electric bill. Each household's share of the total bill is often based on the number of electric points that a household has. Electric points are typically assigned on the basis of the number of electric devices owned by the household and are thus an alternative measure of a household's relative wealth. We asked each respondent how many electric points his or her household had been assigned. Third, we asked respondents to estimate their household's total weekly expenditures, excluding rent. ${ }^{8}$

We thus have three different measures of households' socioeconomic level: (1) number of assets owned, (2) number of electric points, and (3) weekly expenditures. Table 4 reports these three measures

TABLE 4

Number of Households in a Building versus Household Socioeconomic Status

\begin{tabular}{lccc}
\hline $\begin{array}{l}\text { Group and Number } \\
\text { of Households } \\
\text { in the Building } \\
\text { or Compound }\end{array}$ & $\begin{array}{c}\text { Average } \\
\text { Number of } \\
\text { Assets Owned } \\
\text { by Household }\end{array}$ & $\begin{array}{c}\text { Average } \\
\text { Number of } \\
\text { Electric Points }\end{array}$ & $\begin{array}{c}\text { Wverage Household } \\
\text { Weekly Expenditures } \\
\text { (Cedis)* }\end{array}$ \\
\hline A. $1-4$ & $3.29(76)$ & $3.33(49)$ & $7,452(73)$ \\
B. $5-8$ & $2.54(111)$ & $3.10(102)$ & $5,985(106)$ \\
C. $9-12$ & $2.10(137)$ & $2.18(126)$ & $5,216(134)$ \\
D. $13-16$ & $2.27(77)$ & $2.35(72)$ & $4,813(77)$ \\
E. $17-20$ & $2.45(64)$ & $2.40(63)$ & $5,360(63)$ \\
F. $>20$ & $2.28(74)$ & $2.51(70)$ & $5,392(73)$ \\
\hline
\end{tabular}

Note.-Numbers in parentheses are the number of household observations.

* In 1989 US $\$ 1=350$ cedis. 
for households with metered private water connections and living in different-sized buildings or compounds. ${ }^{9}$ As expected, households located in buildings with fewer households (i.e., one to eight households) have the highest socioeconomic level as measured by all three indicators.

Table 5 presents $t$-statistics for a series of pairwise comparisons of sample means of the socioeconomic status (as measured by each of the three indicators) of households in buildings with different numbers of households. As shown, the difference in socioeconomic status between households in group A (one to four households) and households in all other groups is almost always statistically significant for all three indicators of socioeconomic status (the only exception is the group A vs. group B comparison for number of electric points). These results confirm the hypothesis that households in buildings with one to four households have a higher socioeconomic status than households in all other groups, but particularly compared with households in buildings with more than eight households.

The results of the comparisons between group B (five to eight households) and groups $\mathrm{C}-\mathrm{F}$ are more mixed. The $t$-statistics are positive for every comparison for all three indicators but are consistently statistically significant only for number of electric points. The comparisons among groups $\mathrm{C}-\mathrm{F}$ indicate that there are no statistically significant differences between any of the groups that show up for more than one indicator of socioeconomic status.

Despite the imprecision in the measures of households' socioeconomic level, the data in tables 2-5 support the initial hypothesis that relatively better-off households live in low-density housing in buildings with one to eight families and pay the lowest average price for water $(0.25-0.29$ cedis per gallon; see table 2$)$. The relatively poorest households (with private water connections) appear to live in buildings with more than eight households and pay higher average prices $(0.32-0.36$ cedis per gallon).

Table 6 compares the average water bills and average socioeconomic level for households with different means of obtaining water. The mean water bill for households buying water from neighbors by the bucket ( 609 cedis) is $53 \%$ higher than for households with a shared metered connection (397 cedis) and is $156 \%$ higher than for households buying water from neighbors and paying a flat rate $(256$ cedis $) .{ }^{10}$ Moreover, all three measures of socioeconomic level (i.e., number of assets, electric points, and weekly expenditures) indicate that households buying water from neighbors and paying by the bucket are the poorest of the three groups of households. For example, households paying by the bucket have a mean of 1.56 assets, compared with 2.29 assets for households with a shared metered connection and 1.84 assets for households buying from neighbors and paying a flat rate. 


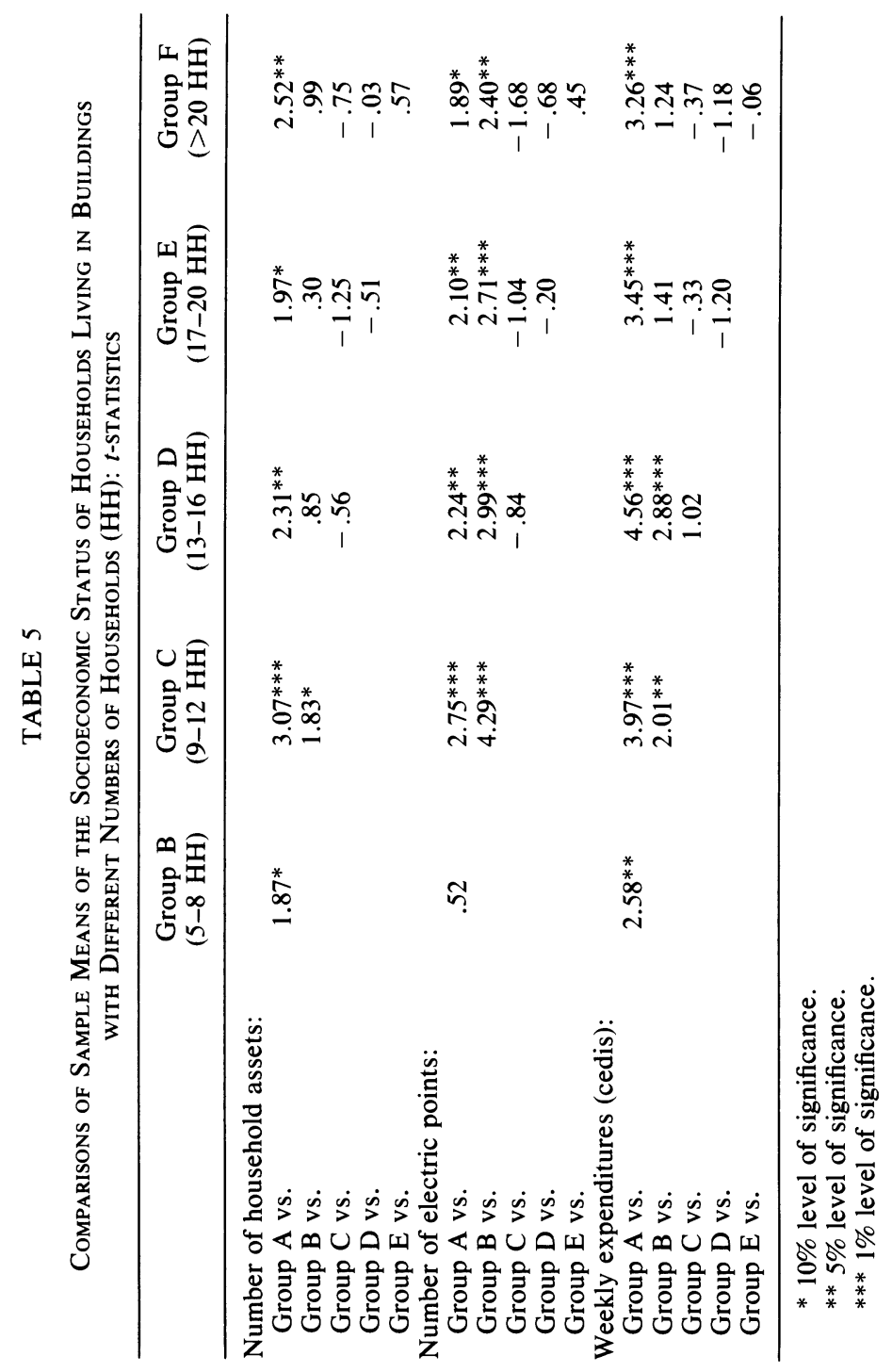


TABLE 6

Monthly Water Bills and Socioeconomic Level for Households With Different Water Sources

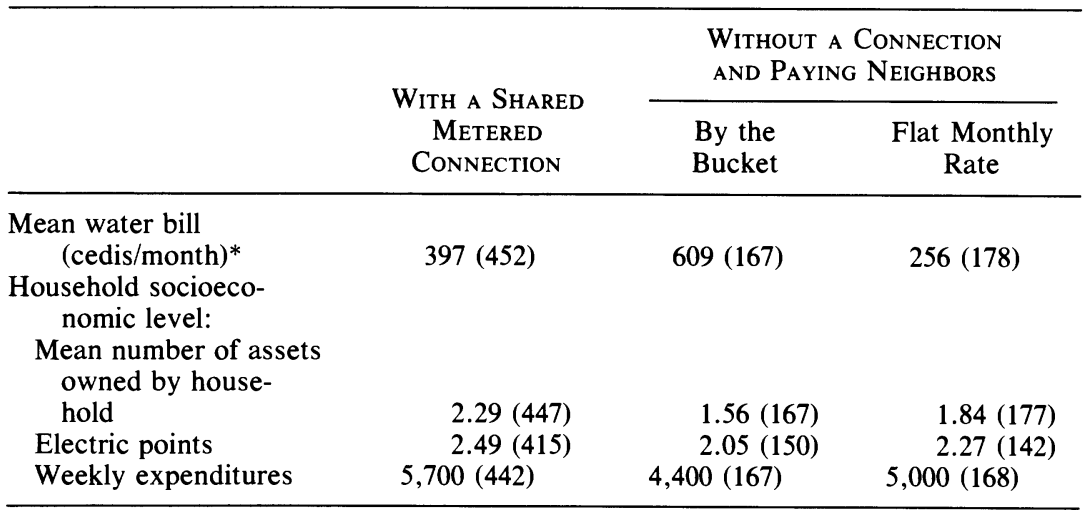
the cell.

NotE.-Numbers in parentheses are the number of household observations for

* In 1989 US $\$ 1=350$ cedis.

These data in table 6 thus show that the poorest group of households-those buying from neighbors and paying by the bucket-are paying the most per month for water. The IBT structure does nothing to protect them and, in fact, appears to exacerbate their situation.

\section{Concluding Remarks}

The findings from the survey in Kumasi show that the increasing block tariff is not achieving its objective of helping the poor to obtain water at minimal cost. Quite the contrary - the poor often pay higher average water prices than better-off households. There are two reasons why this is so. First, households in high-density housing conditions, who often share a single water connection, must pay more per unit under the IBT structure than households that share a connection with only a few others. Second, many low-income families do not have private connections at all and purchase water from neighbors, who thus become caught up in increasing block rates as well and probably pass them along to the buyer. These conditions will not, of course, occur in all developing countries, and where they do not exist the use of IBT structures may be appropriate. However, the regressive effects of IBT structures discussed in this article are almost certainly a problem with water pricing policy in other developing countries as well as in Ghana.

These disadvantages of IBT structures are not limited to water tariffs. Increasing block tariffs are also commonly used for pricing 
electricity with precisely analogous results. For example, most buildings in Kumasi have a single electric meter, and households share a common electric bill. The greater the number of households in a building, the greater the building's electricity consumption, and the greater the proportion of the bill that is assessed at the highest block rate.

It is possible to envision a retailoring of the IBT structure that would address these problems by charging differential rates for buildings with different numbers of households and charging adjusted rates for households that sell to neighbors. For example, in some countries in Latin America the water utility assigns apartment buildings points on the basis of the number of households living there. The greater the number of points, the greater the quantity of water sold at the lifeline rate. But in some situations adjustments of this kind can be difficult to administer and are subject to abuse. For example, when extended families (of perhaps 20-40 people) share a building or compound, the concept of a "household" is not easily defined for billing purposes. Moreover, such adjustments do not address the inequities that arise from resale of water to households without connections.

The objective of this article has not been to offer a comprehensive analysis of the pros and cons of alternative water pricing strategies, but simply to point out how unintended effects of IBT structures can arise in some common situations in developing countries. There is, however, one simple and obvious solution that would go far toward eliminating the IBT structures' adverse effects on the poor (where such adverse effects exist): a uniform tariff, charging the same price for every unit regardless of volume. A single-price tariff structure would be simple to administer, easy for consumers to understand, and more equitable than existing IBTs in situations such as currently exist in Kumasi. On the other hand, a uniform tariff may be politically difficult to implement at a level high enough to generate sufficient resources for the water utility because the middle and upper classes may object to the elimination of the subsidies they often receive from existing pricing policies.

How the level of a uniform tariff should be determined is a subject beyond the scope of this article. It has, however, been a long-standing policy of the World Bank that to the extent possible the price of water should be set equal to the marginal cost of supply. Modifications to a marginal cost pricing rule may be necessary to meet objectives other than economic efficiency, but the burden of proof is typically on the party proposing the modification to show that a departure from marginal cost pricing achieves other social objectives, such as equity. The findings presented in this article show that the standard arguments made in favor of an increasing block type of modification may not be valid in some cities and towns in developing countries. 
Notes

* This article is the result of a joint effort of the Water and Sanitation and Urban Divisions of the Infrastructure and Urban Development Department, the World Bank. Luz Keta Ruiz served as research assistant on the Kumasi study and assisted with the data analysis presented in this article. The following individuals provided helpful comments on an earlier draft of the article: Blair Bower, John Briscoe, Robert Buckley, Michael Cohen, Mike Garn, Andrew Hamer, Ian Hege, David Howarth, Lars Jeurling, Emmanuel Jimenez, Donald T. Lauria, Laszlo Lovei, Frank Mitchell, Daniel Okun, Elaine Patterson, Michael Pommier, Gay Prenoveau, Karen Ramussen, Anthony Van Vugt, and Albert Wright.

1. During the summer months lawn watering accounts for a large proportion of residential water use in many cities in the United States, most of it concentrated in middle- and upper-income households.

2. Residential metering is not currently widespread in the United Kingdom, nor in New York City. However, both are actively undertaking retrofitting of residential water meters.

3. The term "marginal price" is defined as the price to the owner of the connection of the last (highest-priced) unit used. For example, suppose that the lowest (first) block of water is priced at $\$ 5$ per 1,000 gallons, and all water use above 1,000 gallons is priced at $\$ 10$ per 1,000 gallons. If a household used 2,000 gallons, its total water bill would be $\$ 15$. Its marginal price would be $\$ 10$ per 1,000 gallons; its average price would be $\$ 15 / 2=\$ 7.50$ per 1,000 gallons.

4. Dale Whittington, Donald T. Lauria, and Xinming Mu, "Willingness to Pay for Water in Onitsha, Nigeria," World Development 19, no. 2/3 (1991): 179-98.

5. All references to "gallons" are to "imperial gallons." One imperial gallon equals 4.546 liters.

6. At first glance it might appear that a third reason for lower water use per capita in more crowded housing situations would be that higher average prices of water would lead to a reduction in use because of the price elasticity of demand for water. However, this is not likely to occur because of the way water bills are shared (see table 1). If there are 20 households in a building served by a single tap and water bills are shared more or less equally, a single household cannot have a significant influence on its own share of the water bill by reducing its use and is thus unlikely to respond to the aggregate high average cost of water to the building. Indeed, the effect is just the opposite: each household has an incentive to free ride and use excessive amounts of water because the marginal cost to itself of additional water use is very low. This situation would exist in most shared housing arrangements and is probably not too sensitive to the number of households in the building above some minimum number. An important implication of this incentive to free ride is that the use of an IBT structure is not likely to achieve its objective of discouraging "extravagant" water use. Evidence of free-rider behavior in such circumstances has not, however, been documented. It may be that a combination of social pressures and a sense of responsibility to the group prevent households from using "too much" water.

7. These estimates are based on a sample of 84 households. This is much smaller than the total sample size because not all households have metered private connections in their building, and only $22 \%$ of those that do have connections share the water bill equally among households in the buildings.

8. Most housing units in Kumasi are subject to rent controls, and thus the amount of rent a household pays is not a good measure of the quality of the housing unit or the household's socioeconomic level. 
9. The results presented in tables $4-6$ are based on a much larger sample of households than the results in table 3 because the data in these tables do not require that a household share its water bill equally with other households in the building.

10. One reason that households paying a flat rate have so much lower monthly expenditures than households paying by the bucket may be that paying a flat rate does not entitle the consumer to as much water as he or she wants, but to an (implicit) maximum number of trips per day. On the other hand, a pay-by-the-bucket arrangement may entitle the consumer to as much water as he or she is willing to pay for. Households paying by the bucket are probably spending more than $3 \%$ of their income for water. In contrast, households with a shared metered connection and households buying from neighbors and paying a flat rate are spending less than $2 \%$ of their income for water.

American

Journal of Agricultural

Edited by Richard Adams and Steven Buccola Economics

\section{May 1992}

Articles: Gordon C. Rausser and Pinhas Zusman, "Public Policy: Explanation and Constitutional Prescription"; Eric O'N. Fisher and Harry de Gorter, "The International Effects of U.S. Farm Subsidies"; Alain de Janvry and Elizabeth Sadoulet, "Agricultural Trade Liberalization and the Low Income Countries: A General Equilibrium-Multimarket Approach"; S. Devadoss, "Market Interventions, International Price Stabilization, and Welfare Implications"; Howard D. Leathers, "The Market for Land and the Impact of Farm Programs on Farm Numbers"; J. Stephen Clark and Curtis E. Youngblood, "Estimating Duality Models with Biased Technical Change"; G. Scott Smith and Michael E. Wetzstein, "A Stochastic Asset Replacement Model for Rejuvenated Assets"; James A. Duffield and Robert Coltrane, "Testing for Disequilibrium in the Hired Farm Labor Market"; Richard B. Standiford and Richard E. Howitt, "Solving Empirical Bioeconomic Models: A Rangeland Management Application"; Julie A. Caswell and Daniel I. Padberg, "Toward a More Comprehensive Theory of Food Labels"; Roger A. Dahlgran and Steven C. Blank, "Evaluating the Integration of Contiguous, Discontinuous Markets"; plus other articles, comments, and book reviews.

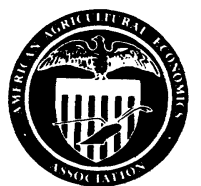

Annual membership dues (including Journal) \$60; Annual library subscription rate \$90; Individual copies \$18.00; Contact AAEA Business Office, 80 Heady Hall, lowa State Univ, Ames, IA 50011. Published in February, May, August, November, and December. 